\title{
Research on the Innovation Mode of International Monetary System
}

\author{
Aiwei Zhang \& Haiyong Ma \\ School of Economics \& Management \\ Changchun University of Science and Technology \\ Changchun 130022, China \\ E-mail:mhymark@gmail.com
}

Received: April 29, 2012

Accepted: May 16, 2012

Online Published: June 15, 2012

doi:10.5430/bmr.v1n2p135

URL: http://dx.doi.org/10.5430/bmr.v1n2p135

\begin{abstract}
In existing international monetary system, the American dollar holds the absolute hegemony. After the sub-prime crisis, the Government of United States holds a laissez-faire policy of U.S. An effective international monetary system should help to promote international trade and investment, and achieve equitable distribution of dividends among countries. Existing international monetary system faces prominent defects, such as the supply and demand imbalance of reserve currency, lack of self-driven adjustment mechanism, and extremely unstable flow of capital in the world. To reform the international monetary system has become the trend of the times. In a long period of time, the global economy cannot get rid of dependence on the U.S. market. The status of America, as the supplier of final product market, will not undergo significant changes. The modes for its reform and innovation mainly include the multi-standard monetary mode, the super-sovereign currency mode, and the American dollar mode.
\end{abstract}

Keywords: Financial innovation, International monetary system, Sub-prime crisis

\section{The current situation of international monetary system}

In existing international monetary system, the American dollar holds the absolute hegemony. After the sub-prime crisis, the Government of United States holds a laissez-faire policy of U.S. dollar. As the global economy gradually stabilizes, the function of U.S. dollar and assets as a safe haven is weakened. People begin to question the issue of reserve currency under the dollar standard system since it lacks constraints. The world has to reconsider the existing world economic order. Although countries explore new reasonable international monetary system at present, the dollar will not lose its hegemony fundamentally. Simply speaking, it has the following reasons: First, the United States is still the No.1 in world economy, which does not change. Secondly, there is not any new international currency which is stable and right for replacing the U.S. dollar.

Although the U.S. dollar is still at the dominant position, the euro has emerged. During more than one dozen years since the birth of the euro in 1999, it has become the international currency only second to the U.S. dollar. At present, 17 countries join in the euro zone and more and more countries have euro as the reserve currency. In December 2009, the euro zone suffers from the debt crisis, the biggest test in 11 years. The depreciation of the euro is temporary. Europe's balance of payments is better than that of America apparently. The euro will not continue to depreciate. Generally speaking, the Europe only faces the problem of national debt. The problem of external sovereign debt is not serious. For example, Germany's the international investment position is positive and Europe's balance of payments is good. At this point, Europe is better than America.

The subprime crisis shakes the basis of the dollar standard system from economic base and government credit, which brings about opportunities for other currencies. During the APEC meeting in Shanghai in 2001, Robert A. Mundell, known as the "Father of Euro", expressed his view on changes of world currency mode in future. He predicted that in the next 10 years, there would be three currency zones in the world, namely the euro zone, the dollar zone, and the Asian currency zone. Under the situation of reducing global currency, the trend of China, Korea, Japan, and other Asian countries using the same currency is coming. Asian dollar can be circulated in Korea, China, Japan, and member countries of ASEAN (the Association of Southeast Asian Nations). The trade between Asian countries increases faster than that in America and Europe. Therefore, economists predict that the birth of Asian dollar might be sooner than imagination. The subprime crisis gives more supports for the popularization of Asian dollar. Because 
of the continuously increasing regional interdependence, the stability of financial system and the economic growth cannot be separated from regional coordinative development and financial cooperation.

\section{The practical significance of international monetary system reform and innovation}

The existing international monetary system is unstable and not fair. Under the existing international monetary system, the U.S. dollar has the privilege but seldom constraint, so that there is a tendency to be irresponsible. The United States often threats the economic development of other countries by means of the dollar standard system. For example, as some countries advocate for a strong dollar, America appreciates the dollar, which alleviates the world inflation but deprive other countries again.

The defects of the existing international financial market system are mainly in three aspects. The first is the supply and demand imbalance of reserve currency. The dollar is still the main reserve currency. Although the U.S. economy merely accounts for $24 \%$ of global gross domestic product, $42 \%$ of sovereign debts, $52 \%$ of bank loans, and $64 \%$ of international reserves are recorded in U.S. dollar. The U.S. dollar is affected significantly by the macro economy policy of the United States so that the supply and demand of global reserve currency cannot achieve the balance. The second is the absence of automatic adjustment mechanism. When a crisis occurs, the financial market system cannot achieve the self-adjustment. Risks accumulate fast in a short time period. The third is the extremely unstable flow of capitals in the world. From 2002 to 2007, in the newly emerging market, the difference of peaks and troughs of capital flow is even equal to $5 \%$ of the gross domestic product of the new economy. However, the new market cannot absorb the 5\% difference because the market is too small and lack of regulatory framework.

The International Monetary Fund (IMF) is trying to make a reform, hoping to build a new international monetary system in a more positive and effective way, and advocating the diversity of international reserve currency. An effective international monetary system should help to promote international trade and investment, and achieve equitable distribution of dividends among countries. We can judge whether the international monetary system is effective or not by three standards: adjustment, liquidity, and credibility. Adjustment means the correction mechanism for the balance of international payments. An effective international monetary system should be capable of correcting the imbalance at lowest costs and fastest speed. Liquidity means an effective international monetary system should provide the right amount of reserve assets, ensuring that the correction of imbalance of international payments would not cause global inflation or deflation. Credibility means the effectiveness of imbalance correction mechanism and the maintenance of international reserve assets value.

\section{The future mode for the international currency reform and innovation}

The first is the multi-standard monetary mode. The U.S. dollar faces stronger competition today. The international financial crisis and worries for the sustainability of debts make people begin to doubt the long-term value of dollar. In international trade, there is a new tendency of using euro, pound, Japanese Yuan, Swiss Franc, and other currencies in trade.

Although the international trade is mainly based on U.S. dollar from 1999 to 2011, the use of other currencies slowly grow in settlement. According to IMF statistics, from 1999 to the first half of 2010, the proportion of dollar-based assets to global foreign exchange reserve fell from $71 \%$ to $61.5 \%$. Promote the reform of international monetary currency, which might be a multi-currency reserve system in future. Build a trans-national "repository" and "credit pool". A multi-currency reserve system is a basic mode. It would tend to inhibit the instability caused by the single sovereign currency as the international currency. Because of the existence of multi-currency reserve system, any one of currencies cannot take international responsibilities initiatively, thus avoiding some irresponsible monetary policies. This monetary system can promote better monetary policies, especially the issuance policy of reserve currency, making them more responsible. In this sense, the multi-currency reserve system should be welcome.

The second is the super-sovereign monetary mode. The super-sovereign international reserve currency is the international reserve currency that is independent from the sovereign state and capable of maintaining the stability of value. To avoid the internal defects of the sovereign credit currency as the reserve currency is the ideal goal of international monetary system reform.

As early as the very beginning of exposure of defects of Bretton Woods System, the IMF created the Special Drawing Rights (SDR) in order to mitigate the internal risks of sovereign currency as the reserve currency. Unfortunately, due to the restrictions of the distribution mechanism and the implementation scope, SDR fails to exert its effect completely even today. SDR possesses the characteristics and potentials of being super-sovereign reserve currency. To expand the issuance of super-sovereign reserve currency can help the IMF to overcome difficulties in costs, voices, and representation. The super-sovereign reserve currency not only overcomes the internal risks of 
sovereign credit currency, but also provides possibilities for adjusting the global liquidity. To centralize and manage a part of global reserve funds by a trustworthy international institution, and provide a reasonable rate of return can

attract the participation of countries. Compared with the separate use of reserve funds by countries, it can better prevent the speculation and market panic and achieve the stability. For all participating countries, it can help to reduce the required reserves and save funds for development. The super-sovereign currency makes the creation and adjustment of global liquidity possible. As one country's sovereign currency is not the reference and standard for global trade, the policy of exchange rate can adjust the imbalance better. It can significantly reduce the risk of future crisis and improve the ability of handling crisis.

The third is the dollar mode. After the outbreak of financial crisis, all central banks of countries did not rush to sell assets, but hurry to purchase dollar assets. In 2009, the net increase of global foreign exchange reserves reached more than 600 billion dollars. $86 \%$ of foreign exchange transactions were based on U.S. dollar. Therefore, the dollar assets still have a strong attractive power.

The U.S. dollar remains a strong currency. Even for the ambitious and powerful euro, though after the fast development in ten years, it cannot shake the status of dollar. In particular, since the European debt crisis in 2009, in the context of fiscal austerity of many countries, economies of countries in the euro zone will growth slowly in a short period. In 2011, the growth rate might be only $0.4 \%$. In May 2011, the gloomy dollar turns defeat into victory. Accompanied by the serious European debt crisis and more worries of global economy recovery, the U.S. dollar outperforms stocks, commodities, and equities. The strong economy supports the value of dollar. In perspective of changes of international division of labor, the "financial hegemony" of the United States will last for a while. In a long period of time, the global economy cannot get rid of dependence on the U.S. market. The status of America, as the supplier of final product market, will not undergo significant changes. As what was said by U.S. President Barack Obama, the dollar's strength ultimately depends on the strength of the U.S. economy. The "strength of fundamentals" of U.S. economy will be the final factor determining the value of the dollar.

\section{References}

Zhu, Min. (2010). Three major defects in the International Financial Market System. China Securities Journal. June, $18^{\text {th }}$.

Zhang, Yuyan \& Tian, Feng. (2010). World economy in 2009 and prospect for 2010. Theory. No.2.

Zhou, Xiaochuan. (2009). Reform of international monetary system should make best use of SDR. China Securities. March, $24^{\text {th }}$. 